\title{
IMPLEMENTATION OF SURVEY AND THREE-DIMENSIONAL MONITORING OF ARCHAEOLOGICAL EXCAVATIONS OF THE KHIRBAT AL-DUSAQ SITE, JORDAN
}

\author{
Alby E. ${ }^{1}$, Vigouroux E. ${ }^{2}$, Elter R. ${ }^{3}$ \\ ${ }^{1}$ Photogrammetry and Geomatics Group, ICube Laboratory UMR 7357, INSA Strasbourg, France \\ emmanuel.alby@insa-strasbourg.fr \\ ${ }^{2}$ French Institute of the Near East \\ elodie.vigouroux@gmail.com \\ ${ }^{3}$ Lorraine university, EA 1132 Hiscant-Ma \\ elter.archeo@wanadoo.fr
}

Commission II, WG II/8

KEYWORDS: Photogrammetry, Archaeology, Bath, documentation, 3D modelling

\section{ABSTRACT:}

In this paper will be presented the use of photogrammetry integrated to the process of representation of an archaeological site. The Khirbat al-Dūsaq site, Jordan, is an architectural complex composed by three remaining buildings with different shapes and functions. The first one is a reception building name îwān. The second one is vaulted and its function has not been determined yet. The third is a bath with all the complexity that are required for such a function (multiple rooms and sequence of spaces). The site is being excavated and there remains unknown information archaeologists want to discover and represent. This project takes places after several years of collaboration on different other archaeological sites. During these different projects, methods of acquisition, processes and drawings at different places and stages have been developed and work methods that includes the use of photogrammetry are now integrated to the archaeological practices. There is now a need by archaeologists for ortho-photos to draw precise plans. The integration of photogrammetry into the practice of archaeology on site helps also to reduce the time consumption to survey and to represent excavation activity. The data sets obtained year after year can also be used as a support for 3D reconstruction. The 3D modelling stage begins by integrating the context represented here by 3D textured mesh produced during the process of ortho-photos. The integration of photogrammetry started in 2015 by acquiring pictures from bath building. This work had to be extended to the entire complex so that it has been decided to manage it, in a proper way. In 2016, a survey network has been implemented, and complete photogrammetric data set have been produced. At this time there was a photogrammetric survey reference for all the data sets of the site. Several years of survey means that the project has to adapt to its specific context. The site life during 11 months without archaeological preoccupations signifies that it is evolving, so that in 2017, ground points had disappeared. The possibility to geo-reference future data sets imposes to integrate targets on pictures from 2016 data set. The remaining building walls on site keep their shape enough to be integrated as constant structures over the years. At first it has been decided to integrate photogrammetry technic to the representation process of the Khirbat al-Dūsaq site. It has proved, by the precision and flexibility of processes that good quality representations could be produced and the 3D documentation could be used as a support of 3D reconstruction stage also. Photogrammetric documentation, as soon as it is properly managed over the years can thus be integrated in archaeologic practices and can help to reduce time consuming stages and propose other activity support as $3 \mathrm{D}$ reconstruction.

\section{INTRODUCTION}

Archaeological site documentation is the support of knowledge for researchers. Drawing is a very consistent part of it and it is not possible to localize artefacts and structures easily if survey is not managed properly. It has always been a matter to produce the best drawing to represent more and more information. Photogrammetry have been partly designed for such an application and gives lots of opportunities in managing the process of archaeological excavations. The archaeological site of Khirbat al-Dūsaq, Jordan, is a good occasion to implement photogrammetric methodology in the process of archaeological drawing. Its particularities, location, historical period, scale and remaining structures are converging to the necessity of producing a 3D documentation project. The use of photogrammetry to obtain ortho-photo accelerates the acquisition stage and postpones the drawing process after the step of excavation. Archaeological drawing can be now managed in office without the need to alternate measure and draft. The three-dimensional data set obtained with this technique is a great help to produce $3 \mathrm{D}$ reconstruction model.

\section{KHIRBAT AL-DŪSAQ ARCHAEOLOGICAL SITE}

The Khirbat al-Dūsaq site is located in southern Jordan, $5 \mathrm{~km}$ east of Shawbak Castle as it can be seen in figure 1. It has been built at an altitude of $1270 \mathrm{~m}$, on an elevation overlooking the valley of Wādī al-Nijil. This complex currently consists of three visible buildings organized in an L around a courtyard. The figure 2 display a general plan of the site and shows the nomenclature of the three buildings used below. To the south, the vestiges of a $\overline{1}$ wān (building A) reception room $(8.50 \times 10.50 \mathrm{~m})$ opening onto a rectangular basin (now filled), are preserved, and a rectangular building (B) (10.30 m x $17.8 \mathrm{~m})$, formerly vaulted, is located about ten meters to the north. Adjoining the latter to the north, an elongated building $(C)(16,50 \mathrm{~m} \times 10,50 \mathrm{~m})$ is erected along a rocky escarpment.

The site was rediscovered by European scholars in the midnineteenth century and regularly featured in publications dealing with monuments of the region. However, neither its dating nor its function were established since no work of architectural study or archaeological excavation was carried out there before 2008 . That year, a team of the French Institute of the Middle East led a first mission of surveys to establish the plan of the complex (Pascual et al., 2015). Then, in 2009, a first mission of 
archaeological excavation, focused on building $\mathrm{C}$ and the building A basin, confirmed the presence of a bath on the site (Vigouroux et al., 2015). Figure 3 shows the condition of the building $\mathrm{C}$ in 2015 . For several years, the study project remained in suspense, before being relaunched in 2015 , when work resumed in the bath of building $\mathrm{C}$ which, since the previous mission, was largely damaged by looters.

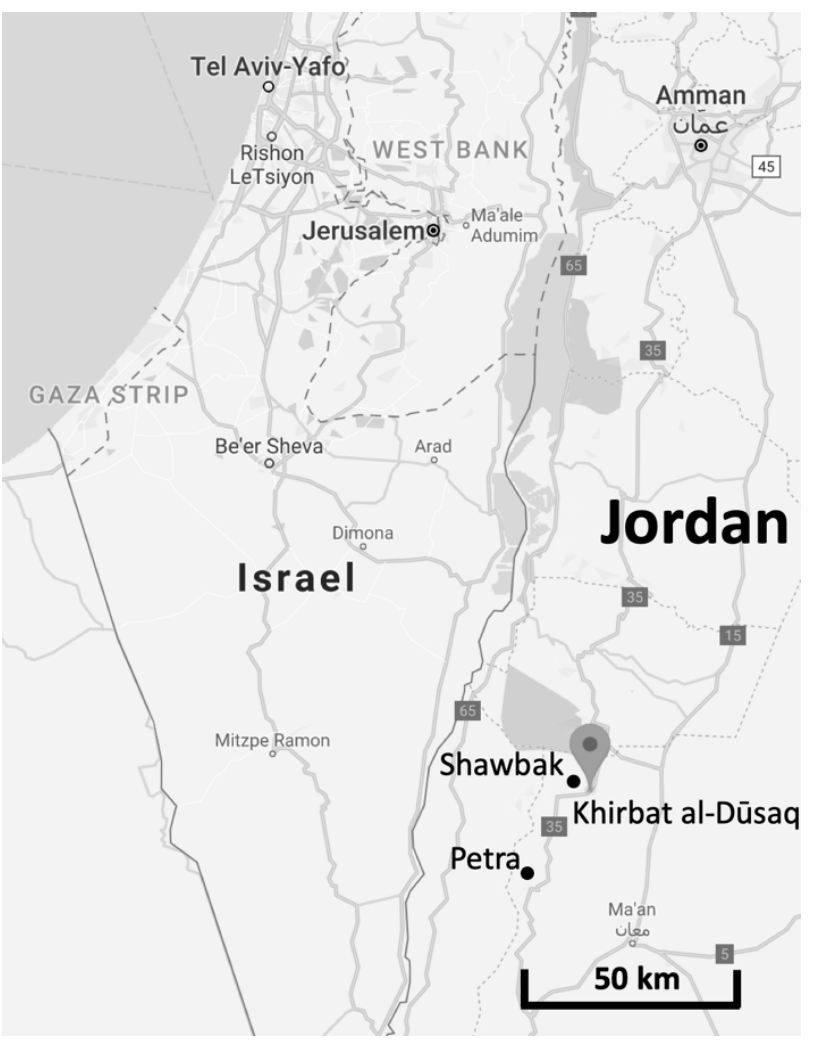

Figure 1: Khirbat al-Dūsaq, Jordan (C google maps)

The combination of the study of the architectural decorations found and the typology of the bath itself had made it possible to date the complex of the medieval period, more precisely of the 13th century. In 2016, an inscription was discovered indicating the date of foundation of the hammam and the identity of the sponsor: the Ayyubid sultan of Damascus, al-Mu'azzam'Isā. The area of Shawbak, crusader's possession since 1145, had been conquered in 1189 by Saladin. At the time of the construction of the complex, at the beginning of the thirteenth century, the authorities undertook the development of these lands. The presence of this luxurious bath attests to the involvement of the prince, nephew of Saladin, in the development of this territory and in particular in the development of the pilgrimage route to Mecca crossing the region. The site was probably abandoned at the end of the Middle Ages, then punctually occupied by shepherds over the centuries, before hosting, at the beginning of the twentieth century, troops during the Great Arab Revolt (19161918).

The excavations were continued in 2017 and 2018, in building B and $\mathrm{A}$, in order to apprehend the articulation of buildings, the organization of spaces and to understand their function. During these years our approach was accompanied by the realization of a systematic photogrammetric coverage allowing notably to document the structures brought to light, to carry out the plans $a$ posteriori and to compare the state of conservation of the buildings year after year.

The site was very damaged by the various reoccupations, but also by the recovery of stone blocks by the inhabitants and finally by looters. The cupolas that covered the bath rooms and the vault of buildings $\mathrm{A}$ and $\mathrm{B}$ collapsed after the abandonment of the site. Therefore, its current appearance does not allow to imagine the dimensions, the high quality of the construction of this princely foundation, nor that of its decor. It was important, for scientific purposes, and for the purpose of communication to the population, to be able to achieve a $3 \mathrm{D}$ rendering of the entire complex. The methodical documentation of the site, as presented in (Al-Ruzouq, 2012) and in (Mirabella Roberti et al., 2019), is a crucial way to preserve information independently of the site development.

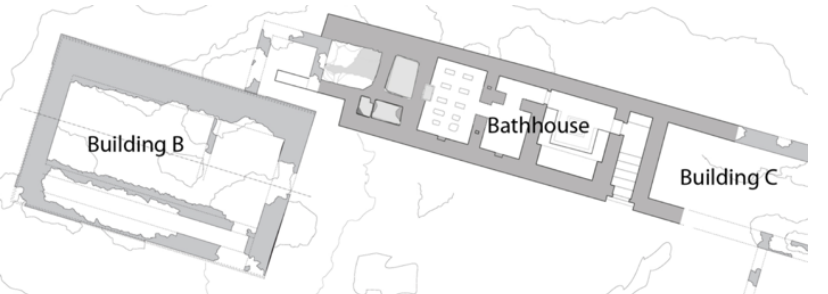

Courtyard

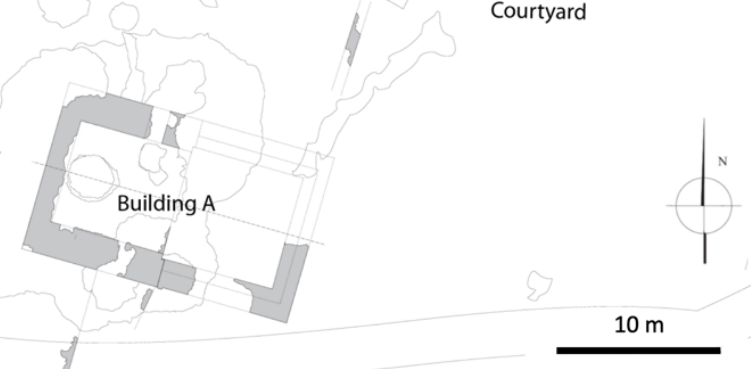

Figure 2: Building A, B and C, Khirbat al-Dūsaq, general plan of the site (2017 CMission Kh. Al-Dusaq, / survey and drawing Ch. March 2008-2009 \& R. Elter 2014, 2017)

\section{4D DOCUMENTATION}

It easier to manage photogrammetric documentation whit only one camera. The reflex we use is a good compromise between quality of pictures and ease of use (Canon EOS 5D mark II). But, to obtain a complete dataset, it necessary to have pictures from the top of the highest structures. The use of 6 meters long telescopic pole is a good solution to obtain missing pictures from this point of view. But the Canon is too heavy for the pole. That is why the Lumix GX7 is used to provide the missing pictures. Tests have been made to validate the combination of the two cameras. Photogrammetric software makes it possible to mix different camera without any problem. This is a methodical matter to consider to orient pictures from human point of view and poles one. It has been decided to have 4 positions of shots to be sure to correctly take benefits of the top point of view. The high of the eye is the easiest to carry. Then the second position with reflex camera is over the head, arm extended. The lower position with the pole is over the top of the wall and oblique, and then the highest position is near vertical position over the wall. The aim of this study is to propose a transdisciplinary point of view about the use of 3D photogrammetric data during archaeological scientific process. It does not have to be proved the effectiveness of this technique to document archaeological site but to underline the gain of time on site and the reliability of the data if it used to produce 2D drawings.

In Khirbat al-Dūsaq, an archaeological investigation takes place each year since 2015 . It is necessary to produce $3 \mathrm{D}$ data of the state of the site. 


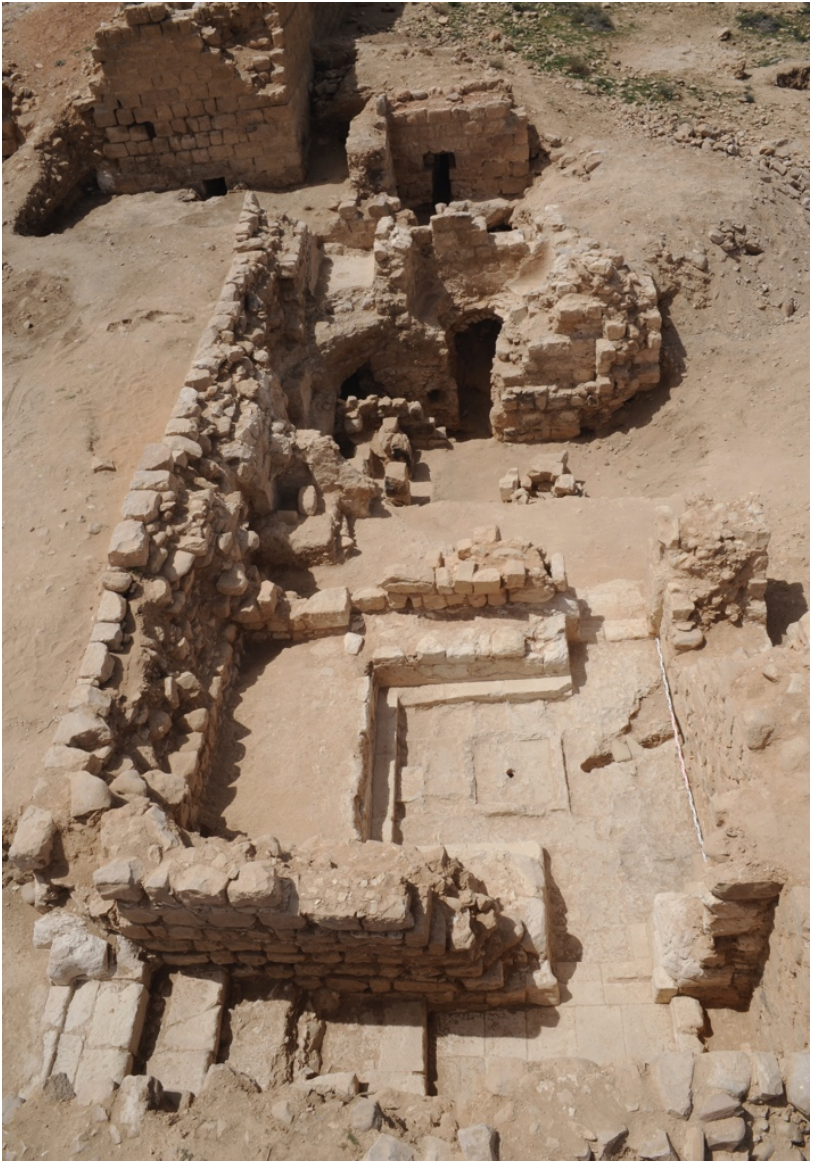

Figure 3: Bath Building (C)
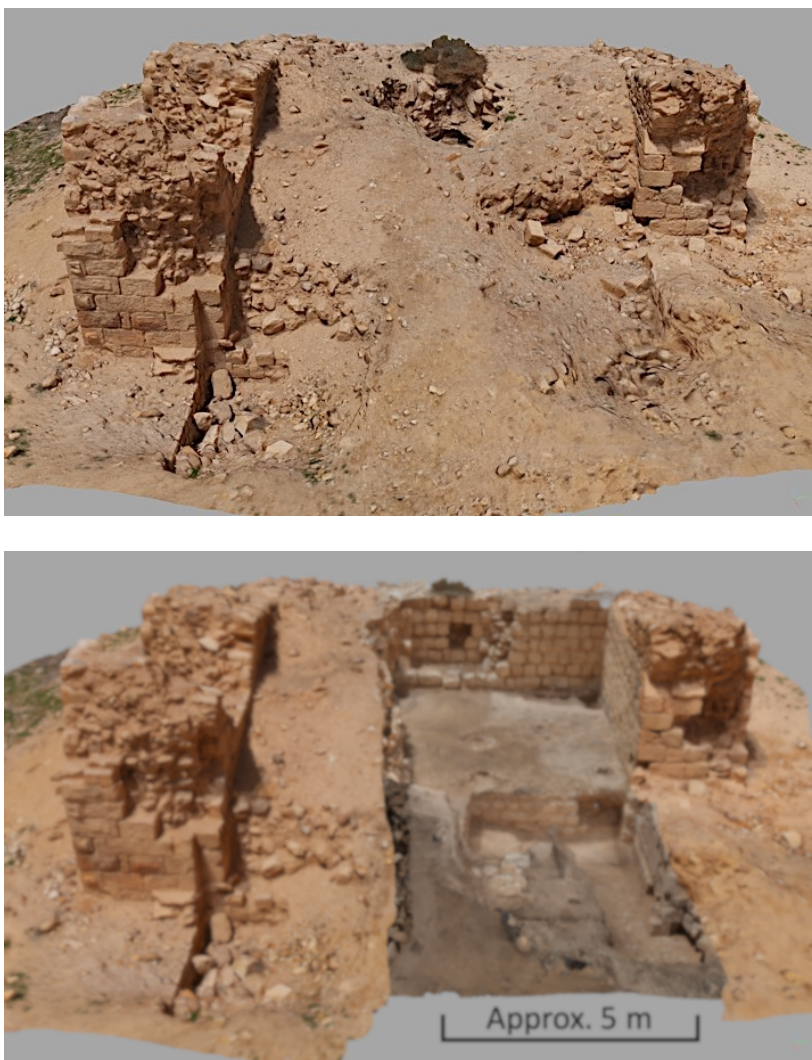

Figure 4: 3D textured mesh model of building A, above in 2016, below superimposition of 2017 excavation.
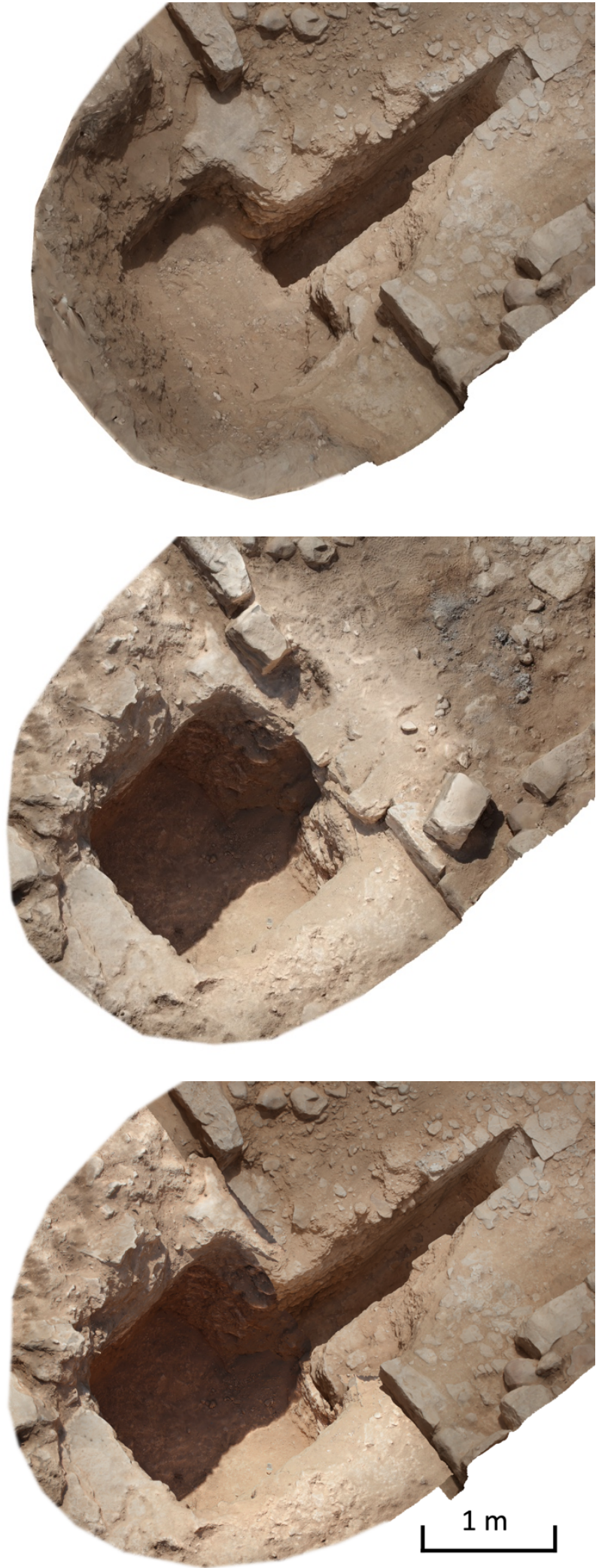

Figure 5: One locus in two missions. above: 2017; Middle: 2018 and below: $3 \mathrm{D}$ fusion of 2 stages.

In 2015 it has been decided to survey the bath building. Hundreds of pictures have been made. A photogrammetric dataset could be processed successfully. An ortho-image of the building of the bath has been produced. 
There were only few metric references to manage scaling of data. There was also some lake of pictures at some parts of the structures. It has been decided to organize a survey more suitable during the next mission.

In 2016 the survey mission has been managed to prepare the work with setting up a reference network that could be reuse during several mission. The control points are recorded in local coordinates. It offers the opportunity to have several photogrammetric projects in the same coordinate system. The acquisition has been managed in two parts. Data sets with coded target were completed and another data set have been made without target to avoid bad textures on final products. The three major buildings were thus georeferenced and could be used as reference for other photogrammetric projects, as soon as a part of pictures with target are used in them. The main goal of this survey mission was to document the major part of the visible structures. Some pictures were taken to complete the lake of past year. At the end of this campaign, the entire site was documented. The archaeological mission has been documented also. It has been possible to produce ortho-image of the major part of the site. Figure 4 give an overview of the interest to record each mission, in 2016 the building A was full and excavated in 2017. The two models have been superimposed thanks to referenced data sets.

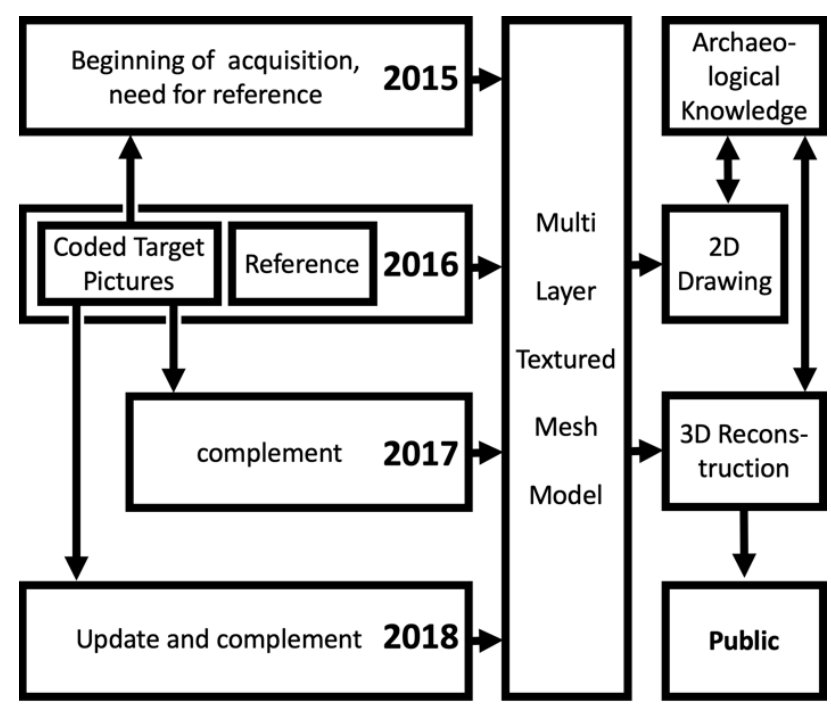

Figure 6: overall process

In 2017, an area has been chosen for archaeological study between to already documented buildings (buildings A and B). As it is often the case, there occurs damages, caused during the period between two research missions. So that 4 refences of a set of 5 have disappeared. It is now impossible to reference new photogrammetric project independently. Hopefully the site was entirely documented past year. It has been shown in (Šedina, 2016), that it is possible to merge different type of photogrammetric data between referenced data set and unscalled project. From the fact that these two structures have already been surveyed, it was easy to reference the new part. Overlapping parts in the new data set have been managed to easy integrate coded target of past year. This method increases the amount of picture to process, but produced good results as soon as the new part to document is between the know structures. Lots of details of archaeological investigation has been covered during this mission. Several sections have been produced and documented. The third year of documentation, in 2018, the same methods was used to merge new data with existing documentation. The area of interest is an extension of the one of 2017. It possible now to produce section from both data set and propose an original point of view on two part that were not seen simultaneously. The error of overall $1 \mathrm{~cm}$ give the possibility to join to half sections side by side and obtain complete representation of water system. Figure 5 presents two nearby excavations that have been merge and can be displayed as one object to produced 2D sections.

It is to notice that the use of the control points is not ideal in this case because they disappeared between to archaeological missions. But, from the fact that there are pictures of coded target on still existing structures on the whole site, it is still possible to manage an acceptable photogrammetric survey.

The complete ortho-photo can be seen in Figure 7. Several projects have been processed to obtain this document.

\section{REPRESENTATION}

The regular and consistent decreases in budgets allocated to archaeological research, both in metropolitan France and in French archaeological missions abroad, have led to a reduction in the duration of excavation operations over time. These budgetary constraints have also had an impact by restricting the numbers of teams that have become smaller today. As a result, it is a real "puzzle" for the scientific leaders of archaeological operations whose questioning is: how to preserve the objectives of archaeological excavation in a limited time and respect the necessary moments and essential to the production of the documentation (plans, elevations and sections)?

The archaeologist "on duty" all around the world can be assigned to a mission but there are nevertheless incompressible processes related to the production of documents!

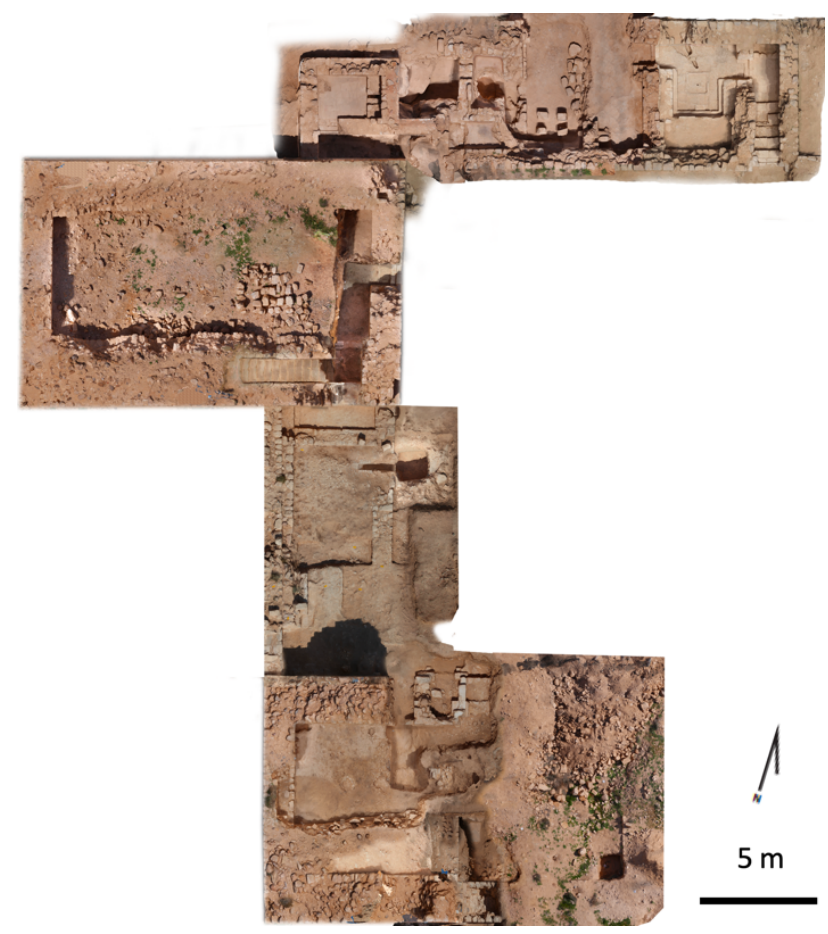

Figure 7: Ortho-Photo of the site from years 2015 to 2018

Since the establishment of the Khirbet Dusaq archaeological mission in Jordan in 2015, an intervention methodology has been developed to enable the production of graphical documents while preserving at best the balance between the period allocated to the excavation and that devoted to surveys.

It was inspired by the method developed, with the logistic and scientific support of Insa Strasbourg (Alby, 2015), by the FrancoPalestinian cooperation team at the Tell Umm el-Amr site, led by René Elter, in the Gaza Strip. There, since 2012, in a constrained 
and very complex context, a program of photogrammetric surveys has been set up (Alby et al., 2013). The urgency of the interventions made it necessary to focus on the excavation stage as much as possible. This restricted to a minimum the production of graphical documents.

This simple methodology allowed after a fine cleaning of the remains or stratigraphic layers to achieve in a few hours all the $3 \mathrm{D}$ documentation of an archaeological campaign of several weeks. In the process, the photographic snapshots were transmitted via internet data transmission to Strasbourg's office to be processed. The following days, an orthophotography was sent to the team in Gaza for verification. This ortho-photo, reliable as a true drawing, became a working tool, which could be annotated and commented.

The production of the final graphical document was thus postponed until the month following the archaeological mission back to France. The time spent drawing on ortho-photos is equivalent to the time needed during a traditional survey. One of the advantages of the method is to provide a very fine drawing and certainly more accurate than from a manual traditional survey. The general plan, resulting of this method, is presented in figure 8 . The production and use of ortho-photo can replace with great gains traditional methods (Alshawabkeh et al., 2010).

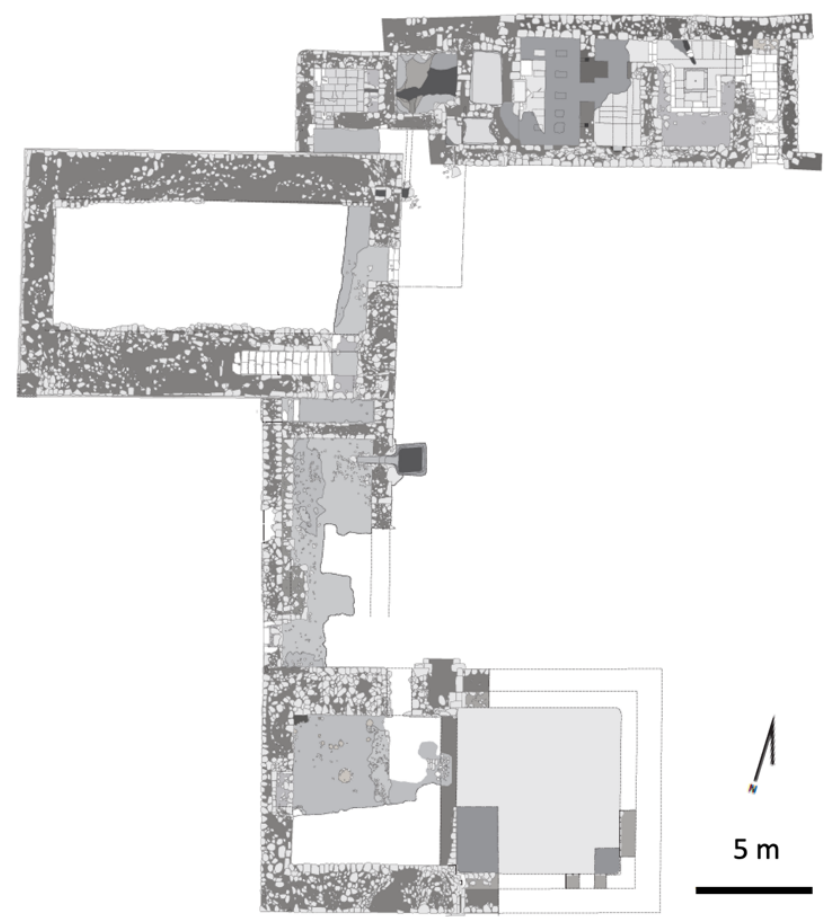

Figure 8: Khirbat al-Dūsaq, general plan of the site (2018 CMission Kh. Al-Dusaq, / drawing R. Elter, photogrammetry E. Alby)

It also avoids the deformations of the paper supports generally damaged during the excavation or those related to the scanning before being cleaned.

The methodology has made it possible for almost ten years to avoid hiring in Gaza a specialized draftsman in archaeological and architectural surveys. Economically, the operation is profitable because it does not require specific hardware for acquisition. The quality of the camera used by the archaeological team is sufficient and reachable skills are required.

At Khirbat al-Dūsaq, the photogrammetry-based surveys were imposed at the start of the operation. They are completed during each mission, excavation after excavation. Field intervention has allowed referencing of past surveys and the positioning of reference points for future interventions. The photographic documentation made during each intervention is carefully recorded and stored. It is the same for the ortho-photos. They are the memory of the excavation site step by step, year after year.

\section{3D MODELING FOR RECONSTRUCTION}

The representation of an archaeological site is a great support to provide good assumptions. It gives an overall point of view of how remaining's structures are organized. The more detailed it is the more precise reconstruction can be produced. The validation of reconstruction is more and more based on $3 \mathrm{D}$ modelling. The integration of $3 \mathrm{D}$ mesh produced during photogrammetric process correspond to the first step. The metric data set can be seen as a digital copy of the archaeological site. The combination of other sites documentations and the 3D mesh of the site can help the archaeologist to guide the production of one 3D model, that validates or not, the assumptions he made. Several versions are proposed and have been compared to choose the more credible one. This iterative process is easy conceivable due to digital format of the model. From the fact that the model originates from assumptions it cannot be too realistic. The degree of certainty is different for each part of the model. The model, as shown in figure 9 does considers this uncertainty. 3D model has two main goals: be a support of archaeological research and a media to communicate afterward. Once the model finished, it can help people to understand the initial shape and use of an archaeological site. Figure 10 represent a cross section of the 3D Model. It helps to understand the constitution od the building of bath.

\section{CONCLUSION}

Nowadays, the management of an archaeological site excavation is more and more stressful. Project founding is very difficult to achieve and the duration and capacity of action on it is decreasing. The time allowed in the past to draw on site can be used to focus on activities that cannot be compressed yet. Four major advantages are resulting from this method. The first deals with the entire 3D documentation of the site for itself. The data sets can be used on the moment they are needed as soon as they are created and stored properly. This is the main goal of cultural heritage documentation. The second is related to the main objective of the project, the capacity to postpone a precise drawing after the mission. The duration of drawing activity is spent on other time as the excavation one. The third one concerns the flexibility of the photogrammetric acquisition. In 2017, the ground points have been lost due to local people activities. Newer referenced data sets can even be produced thanks to the pictures that see common structures with the 2016 data set. Fourth and last advantage is that the data sets are created to obtain orthophotos can also be used to product $3 \mathrm{D}$ reconstruction models. More and more archaeologists are convinced by this numerical practice and the gains they can obtain of it. But it has to be noticed that certain skills have to be mastered to pretend to let the creation of metric data sets in their hands.

As soon as the representation of archaeological site is made by people how have such skills. We now have ortho-photos of archaeological sites and corresponding 2D representations. It thinkable to ask whether it is possible to produce automatically those representation directly from photogrammetric data set. 


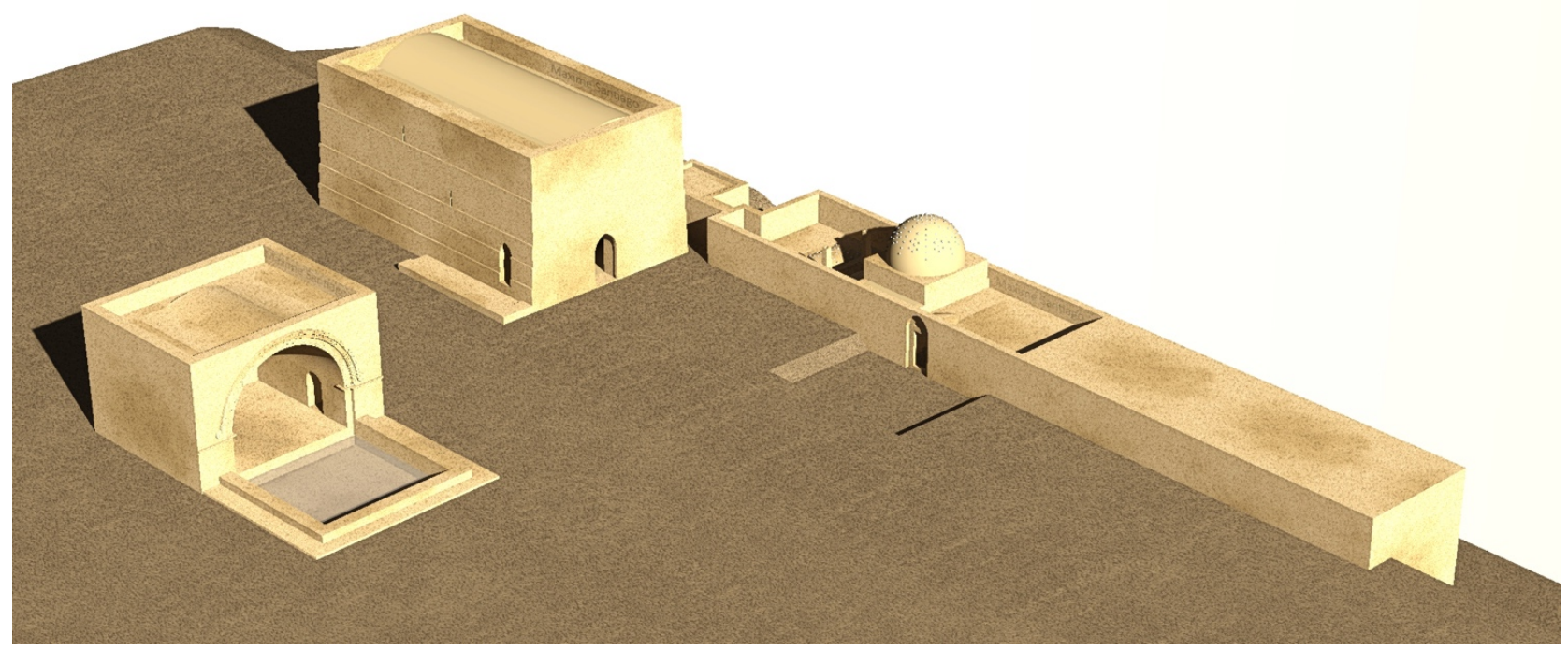

Figure 9: hypothetical Reconstruction of the Site from 3D model

(C) Maxime Santiago (modelling), april 2017-Khirbat al-Dusaq Mission)

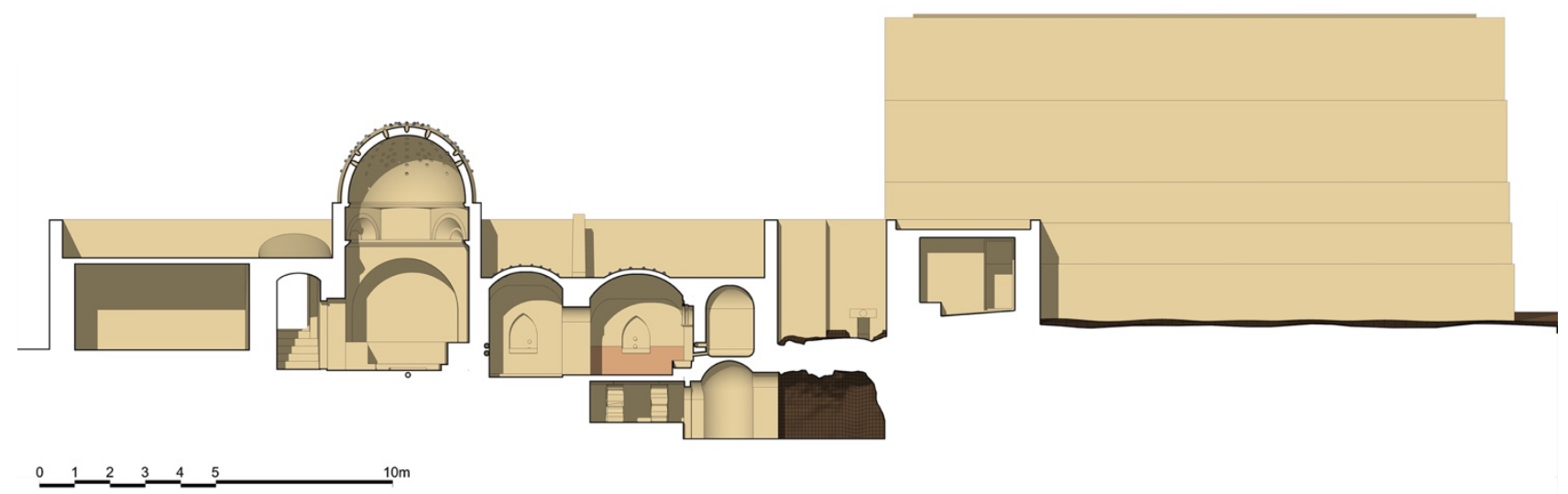

Figure 10: hypothetical reconstruction, section E-W from 3D model of bath (building C)

(C) Maxime Santiago (modelling), april 2017-Khirbat al-Dusaq Mission)

\section{ACKNOWLEDGEMENTS}

The project was funded by the Institut Français du ProcheOrient, the Service de coopération et d'action culturelle de l'ambassade de France in Jordan, the Cnrs, the Swiss Max van Berchem Foundation (2016), the Agence universitaire de la Francophonie (2018) and since 2018 by the commission consultative des fouilles du Ministère de l'Europe et des affaires étrangères.

\section{REFERENCES}

Alby, E., Elter, R., Ripoche, C., Quere, N., 2013. Close Range Photogrammetry Applied to the Documentation of an Archaeological Site in Gaza Strip, Palestine. In: The International Archives of the Photogrammetry, Remote Sensing and Spatial Information Sciences, 1(2), 19-24. doi.org: 10.5194/isprsarchives-XL-5-W2-19-2013.

Alby, E., 2015. Point cloud vs drawing on archaeological site. In: The International Archives of the Photogrammetry, Remote
Sensing and Spatial Information Sciences, XL-5/W doi.org: 10.5194/isprsarchives-XL-5-W7-7-2015.

Al-Ruzouq, R. 2012. Photogrammetry for Archaeological Documentation and Cultural Heritage Conservation. Special Applications of Photogrammetry, Daniel Carneiro da Silva, IntechOpen, doi.org: 10.5772/35314.

Alshawabkeh, Yahya \& Haala, Norbert \& Fritsch, Dieter. 2010. A new true ortho-photo methodology for complex archaeological application. Archaeometry, 52. 517 - 530. doi.org: $10.1111 / \mathrm{j} .1475-4754.2009 .00484 . x$.

Mirabella Roberti, G., Nannei, V., Azzola, P., Cardaci, A., 2019. Preserving the venetian fortress of Bergamo: quick photogrammetric survey for conservation planning. In: The International Archives of the Photogrammetry, Remote Sensing and Spatial Information Sciences, XLII-2/W11. 873-879. doi.org: 10.5194/isprs-archives-XLII-2-W11-873-2019. 
Pascual, J.-P., March, C., 2015. Le complexe médiéval de Khirbat al-Dūsaq (Shawbak), Syria [On Line], http://journals.openedition.org/syria/3507, doi.org: $10.4000 /$ syria.3507.

Šedina, J., Pavelka, K., Housarová, E. 2016. Archaeological documentation of a defunct Iraqi town. In: The International Archives of the Photogrammetry, Remote Sensing and Spatial Information Sciences, XLI-B1. 1031-1035. doi.org: 10.5194/isprsarchives-XLI-B1-1031-2016.

Vigouroux, E., Elter, R., Pascual, J.-P., March, C., 2015. Le complexe médiéval de Khirbat al-Dūsaq (Shawbak), Syria [On Line], $\quad$ http://journals.openedition.org/syria/3177. doi.org: 10.4000 /syria.3177. 